\title{
Detection of estrogen receptors ER-alpha and ER-beta in human ejaculated immature spermatozoa with excess residual cytoplasm Vittoria Rago ${ }^{1}$, Laura Siciliano ${ }^{1}$, Saveria Aquila² and Amalia Carpino*1
}

\author{
Address: ${ }^{1}$ Department of Cell Biology, Faculty of Pharmacy, University of Calabria, Cosenza, Italy and ${ }^{2}$ Department of Pharmaco-Biology, Faculty \\ of Pharmacy, University of Calabria, Cosenza, Italy \\ Email: Vittoria Rago - vittoriarago@yahoo.com; Laura Siciliano - siciliano_laura@yahoo.it; Saveria Aquila - sav_aqui@yahoo.it; \\ Amalia Carpino* - am_carpino@yahoo.it \\ * Corresponding author
}

Published: 17 July 2006

Reproductive Biology and Endocrinology 2006, 4:36 doi:10.1 186/1477-7827-4-36

This article is available from: http://www.rbej.com/content/4/I/36

(c) 2006 Rago et al; licensee BioMed Central Ltd.

This is an Open Access article distributed under the terms of the Creative Commons Attribution License (http://creativecommons.org/licenses/by/2.0), which permits unrestricted use, distribution, and reproduction in any medium, provided the original work is properly cited.
Received: 25 May 2006

Accepted: 17 July 2006

\begin{abstract}
Background: A key role of estrogens in human sperm biology has been recently suggested by aromatase and estrogen receptor detection in human testicular germ cells and ejaculated spermatozoa. However, the involvement of these hormones in the sperm maturation process is still not defined. The aim of this work was to investigate the expression of estrogen receptors, ERalpha and ER-beta, in human ejaculated immature spermatozoa with excess residual cytoplasm.

Methods: Immunofluorescence labelling has been used to localize ER-alpha and ER-beta proteins in immature spermatozoa isolated by Percoll gradient, while Western blot analysis was carried out on sperm protein extracts.

Results: Both estrogen receptors were localized in excess residual cytoplasm of immature sperm, while sperm tails showed only ER-beta. Furthermore, in the same cells, immunoblots detected the presence of the full-length ( $\sim 67 \mathrm{kDa})$ ER-alpha and ( $\sim 59 \mathrm{kDa})$ ER-beta proteins, together with a $\sim 50 \mathrm{kDa}$ ER-beta species, lacking in mature sperm.

Conclusion: The present investigation demonstrated ER-alpha and ER-beta presence in excess residual cytoplasm of human abnormal sperm cells, suggesting the hypothesis that both the 'classical' ERs could be able to mediate estrogen action in spermatogenetic cells. Furthermore, the presence of the short ER-beta form in abnormal germ cells and its disappearance in mature sperm, support estrogen modulation via different ER forms during sperm maturation.
\end{abstract}

\section{Background}

In recent years, a key role of estrogens in differentiation and function of mammalian male germ cells has been suggested by the detection of proteins involved in estrogen biosynthesis and activity. In fact, aromatase and estrogen receptors (ERs) have been revealed in sperm cells at different stages of their maturation process [1-3]. It is known that estrogen action on target cells is mediated by two estrogen receptors, ER $\alpha$ and ER $\beta$, each encoded by a unique gene, differing in the C-terminal ligand-binding domain and in the N-terminal trans-activation domain [4]. Different ER variant isoforms have been also identified, but their biological significance is still unknown. Information about the loss of estrogen receptor activity has been provided by the estrogen receptor gene knock out (ERKO) mouse. These animals showed altered sperm count, motility and morphology in the adulthood [5]. Furthermore, a diminuished sperm viability has also been 
observed in a single case of human inactivating mutation of the ER $\alpha$ gene [6]. These findings suggest the estrogen receptor involvement in the achievement of sperm function.

To date, ER $\beta$ appears to be the predominant form of estrogen receptor in developing human germ cells such as spermatogonia, spermatocytes and spermatids [7-9] as only a single report indicated ER $\alpha$ presence in primary human spermatocytes and spermatids [7]. Recently, a differential cell distribution of ER $\beta$ splice variants (ER $\beta 2$, ER $\beta 4$, ER $\beta 5$ ) during spermatogenesis has been demonstrated $[10,11]$. Furthermore, the total absence of both ERs in seminiferous tubule has been also reported [12]. However, the regulatory role of estrogens during sperm differentiation has not yet been clarified.

Human ejaculate can contain spermatozoa with excess residual cytoplasm which has been retained around the sperm mid-piece due to an incomplete maturation process $[13,14]$. Previous data from our laboratory [15] have demonstrated aromatase expression in cytoplasmic droplets of immature spermatozoa, indicating a local estrogen biosynthesis. The aim of this study was to provide additional data on estrogen involvement in sperm differentiation, investigating the presence of estrogen receptors (ER $\alpha$ and ER $\beta$ ) in human ejaculated spermatozoa with excess residual cytoplasm.

\section{Materials and methods Specimens}

Semen samples have been obtained from patients who attended University Centre for Fertility Evaluation and the ethical committee members of the University of Calabria approved the investigation programme.

Standard semen parameters were determined according to the WHO [16]. Particularly, sperm morphology was assessed by the May-Grümwald Giemsa staining, observing a minimum of 200 spermatozoa for each sample under an oil immersion lens $(\times 1000)$. Selected specimens were 10 ejaculates showing asthenozoospermia and a high proportion (15-25\%) of spermatozoa with excess residual cytoplasm (abnormal mid-piece droplet greater than one third of the size of the sperm head). The ejaculates from 10 fertile donors served as the control group.

\section{Sperm isolation}

Sperm cells were isolated from semen on discontinuous Percoll gradient $(40 \%-70 \%-90 \%)$ by centrifugation at $500 \mathrm{~g}$ for 20 minutes. Spermatozoa with excess residual cytoplasm were recovered from the $40 \% / 70 \%$ interface, while normal sperm were recovered from the $90 \%$ layer.

\section{Antibodies}

Anti-ER $\alpha$ primary antibody was mouse monoclonal F-10 (Santa Cruz Biotechnology, Ca, USA) which recognizes epitope mapping at the C-terminus region of the human native ER $\alpha$. Anti-ER $\beta$ primary antibody was rabbit polyclonal H-150 (Santa Cruz Biotechnology, Ca, USA) which recognizes epitope mapping at the $\mathrm{N}$-terminus regions of human native ER $\beta$. Rabbit polyclonal anti $\beta$-actin (Santa Cruz Biotechnology, Ca, USA) was also used as loading control. Fluorescein isothiocyanate (FITC) conjugated IgG (Sigma Aldrich, Milan, Italy), Texas-Red conjugated IgG (Vector Laboratories, INC, Burlingame, CA) and horseradish peroxidase conjugated IgG (Santa Cruz Biotechnology, Ca, USA) were used as secondary antibodies.

\section{Immunofluorescence assay}

Sperm cells, recovered from Percoll gradient, were rinsed three times with $0.5 \mathrm{mM}$ Tris-HCl buffer, $\mathrm{pH} 7.5$ and were allowed to settle onto slides in a humid chamber. The overlying solution was carefully pipetted off and replaced by absolute methanol for 7 minutes at $-20^{\circ} \mathrm{C}$. After methanol removal, sperm cells were washed in Tris-buffered saline (TBS), containing $0.1 \%$ Triton X-100 and were treated for immunocytochemistry. Anti-human ER $\alpha$ IgG (F-10) (1:50) and anti-human $\operatorname{ER} \beta$ (H-150) (1:100) have been utilized as primary antibodies, while anti-mouse IgG Texas-red conjugated (1:50) and anti-rabbit IgG FITC conjugated (1:50) have been used as secondary antibodies. Sperm cells, incubated without the primary antibodies, were utilized as negative controls. Absorption controls were also performed by using the primary antibodies (F10 and $\mathrm{H}-150)$ preabsorbed with an excess of the related purified antigens (ER $\alpha$ blocking peptide: sc-8002P; ER $\beta$ blocking peptide :sc-6820P, Santa Cruz Biotechnology) (5 $\mathrm{nm} / \mathrm{ml}$ ), for $48 \mathrm{~h}$ at $4^{\circ} \mathrm{C}$. The slides were examined under an epifluorescence microscope (Olympus BX41) with a suitable filter for FITC and Texas-Red, observing a minimum of 200 spermatozoa $\times$ slide $(100 \times$ objective) Fluorescent images were captured on a PM-C35DX camera (Olympus), exposure: 9 sec, and printed on Kodak paper $(15 \times 10)$. The images were then acquired by Epson Expression 1680Pro scanner at 300 dpi in RGB at 12 bit, and compiled using Adobe Photoshop 7 (Adobe System Inc.)

\section{Western blot analysis}

After Percoll removal, sperm samples were re-suspended in lysis buffer (62.5 mmol/L Tris-HCl (pH 6.8), $150 \mathrm{mM}$ $\mathrm{NaCl}, 2 \%$ sodium dodecyl-sulphate (SDS), 1\% Triton $\mathrm{X} 100,10 \%$ glycerol, $1 \mathrm{mM}$ phenylmethylsulfonylfluoride, $0.2 \mathrm{mM} \mathrm{Na}_{3} \mathrm{VO}_{4}, 1 \%$ aprotinin). Lysates were quantified using Bradford protein assay reagent [17]. Equal amounts of protein $(20 \mu \mathrm{g})$ were boiled for 5 minutes, separated under denaturing conditions, by SDS-PAGE on $10 \%$ polyacrylamide Tris-glycine gels, and then electrob- 

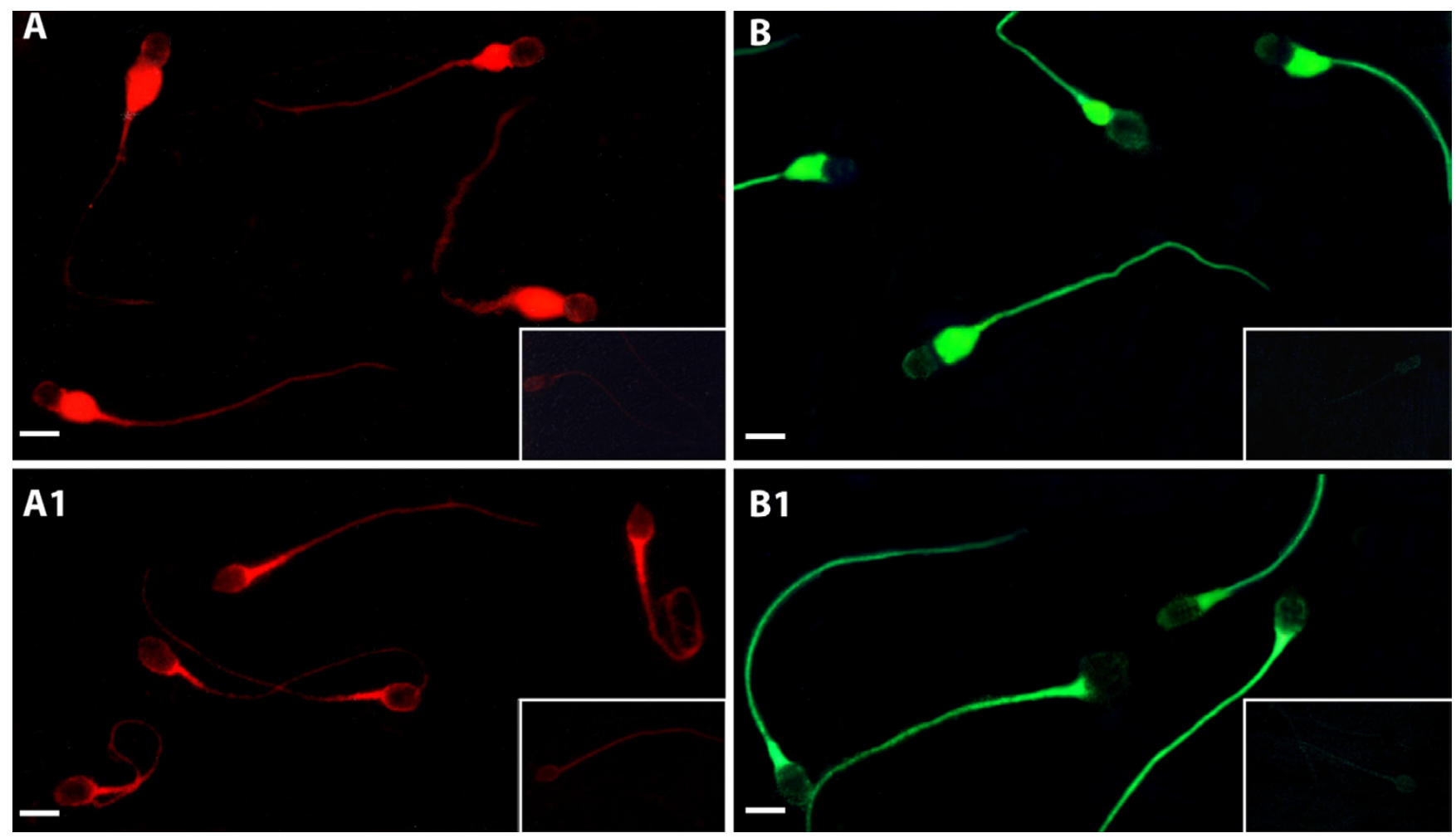

Figure I

$E R \alpha$ and $E R \beta$ immunofluorescence labelling of morphologically normal spermatozoa and spermatozoa carrying superfluous cytoplasm A: ER $\alpha$ red brilliant light (Texas-Red) in excess residual cytoplasm of immature spermatozoa. AI: ER $\alpha$ fluorescence in mid-piece regions of normal sperm. B: ER $\beta$ green intense light (FITC) in excess residual cytoplasm and tails of immature spermatozoa. BI: ER $\beta$ fluorescence in mid-piece regions and tails of normal sperm. Scale bars $5 \mu \mathrm{m}$.

lotted to nitrocellulose membrane. Non-specific sites were blocked with 5\% non fat dry milk in $0.2 \%$ Tween-20 in Tris-buffered saline (TBS-T) for 1 hour at room temperature and incubated overnight with anti-human ER $\alpha(\mathrm{F}-$ 10, 1:500 dilution), anti-human ER $\beta$ (H-150, 1:1000 dilution) and anti-human $\beta$-actin. Then antigen-antibody complexes were detected by incubation of the membranes with the appropriate secondary antibodies (anti-mouse or anti-rabbit horseradish peroxidase-conjugated, Amersham, USA) for $1 \mathrm{~h}$ at $22^{\circ} \mathrm{C}$. The bound secondary antibodies were detected with the ECL Plus Western blotting detection system (Amersham, USA) according to the manufacturer's instructions. Each membrane was exposed to the film for 2 minutes.

Protein extracts from MCF7 (breast cancer cell line) and LnCap (prostate cancer cell line) were cultured as previously reported [18] and used as positive controls for ER $\alpha$ and ER $\beta$ respectively. Negative controls were prepared using sperm lysates where antigens were previously removed by pre-incubation with specific antibodies ( $1 \mathrm{~h}$ at room temperature) and subsequently immunoprecipitated with protein $\mathrm{A} / \mathrm{G}$-agarose.

\section{Results \\ ER $\alpha$ IER $\beta$ immunofluorescence}

A red brilliant light revealed ER $\alpha$ presence in excess residual cytoplasm of immature spermatozoa, while their heads and tails were not labelled (Fig 1:A). Normal sperm showed ER $\alpha$ only in the mid-piece region (Fig 1:A1).

A green brilliant light detected ER $\beta$ in excess residual cytoplasm and in all the tails of immature sperm, but not in their heads (Fig 1:B). Normal spermatozoa revealed ER $\beta$ fluorescence in all the tail regions (Fig 1:B1).

The immunostaining specificity was verified by the absence of immunoreaction in negative controls (data not shown) as well as in absorption controls (Fig 1, inserts) The immunofluorescence experiments were repeated 10 times with similar results.

\section{Immunoblotting}

The anti-ER $\alpha$ antibody detected a single band corresponding to the molecular weight values of $\sim 67 \mathrm{kDa}$ in normal (Fig. 2:A, lane 1) and immature spermatozoa (Fig. 2:A, lanes 2-5), with a major band in the latter. This band co- 
A

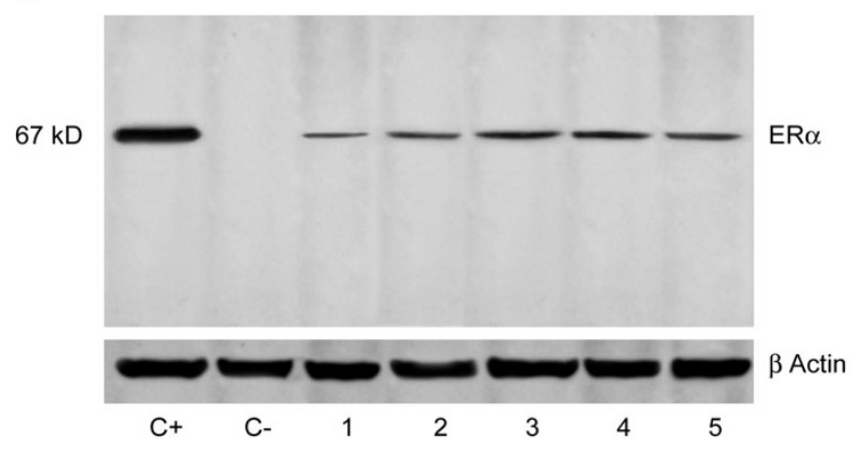

B

$60 \mathrm{kD}$

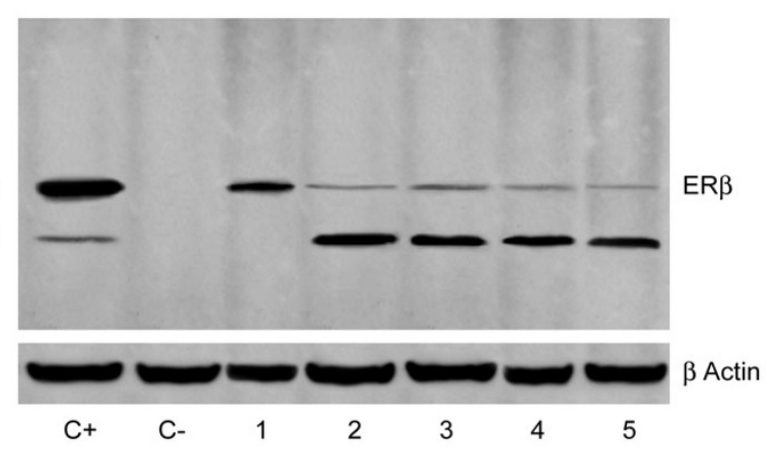

Figure 2

Western blotting analysis of ER $\alpha$ and ER $\beta$ in human immature and mature ejaculated spermatozoa. A. Immunoblots of sperm extracts by using anti-ER $\alpha$ : a $67 \mathrm{kDa}$ band has been detected in positive control (MCF-7 extract) (lane C+), normal sperm (lane I) and immature spermatozoa (lines 2-5); the band was lacking in negative control (lane C-). B. Immunoblots of sperm extracts by using anti-ER $\beta$ : two bands, 59 and $50 \mathrm{kDa}$, have been revealed in positive control (LNCaP extract) (lane $\mathrm{C}+$ ) and immature spermatozoa (lanes 2-5), while normal sperm have shown only the $59 \mathrm{kDa}$ band (lane $\mathrm{I})$; both the bands were absent in negative control (lane C-). $\beta$-actin (in A and B) serves as a loading control.

migrated with positive control band (MCF7) (Fig 2:A, lanes $\mathrm{C}+$ ) while no band has been observed in negative control (Fig 2:A, lane C-).

The anti-ER $\beta$ antibody (Fig 2:B) showed only the expected band at $\sim 59 \mathrm{kDa}$ in normal sperm (Fig 2:B, lane 1), while two bands were revealed in immature spermatozoa: a weaker one at about $\sim 59 \mathrm{kDa}$, consistent with the full length ER $\beta$ size, and a thicker band at $\sim 50 \mathrm{kDa}$ (Fig 2:B, lanes 2-5). Positive control (LnCap) showed both the ER $\beta$ bands (Fig 2:B, lane $\mathrm{C}+$ ) while no band has been observed in negative control (Fig 2:B, lane C-).

The same results have been obtained in all the 10 samples. The figures $2 \mathrm{~A}$ and $2 \mathrm{~B}$ show 4 representative specimens.

\section{Discussion}

In the last stage of mammalian spermiogenesis, the bulk of spermatid cytoplasm is extruded in tubular lumen while a small cytoplasmic mass is retained around the sperm mid-piece as cytoplasmic droplet. This droplet moves to the end of the tail and finally sheds from mature spermatozoa [13]. This process occurs during epididymal transit in non-human species [19-21], but shortly before spermatozoa enter epididymis in humans [22]. Small cytoplasmic droplets are often observed in rapidly fixed preparations of human ejaculated sperm, but they are not considered deleterious to sperm functional properties $[13,14]$.

However, human semen can also contain abnormal spermatozoa with large amounts of excess cytoplasm adhering to the mid-piece, due to an arrest of spermatid differentiation at a late stage of spermiogenesis $[13,14]$. A high incidence of excess residual cytoplasm bearing spermatozoa has been observed in semen from smokers [23] and men with varicocele [24] and defective sperm functions $[25,26]$. Retention of excess residual cytoplasm has been associated with oxidative stress as a consequence of enhanced reactive oxygen species production [27-30].

This is the first report identifying estrogen receptors, ER $\alpha$ and ER $\beta$, in excess residual cytoplasm of human ejaculated immature spermatozoa, consistent with our previous data [15] which showed the presence of aromatase in the same cell site. Aromatase is the enzyme responsible of the conversion of androgens to estrogens, therefore, our past and present data suggest that cytoplasm of testicular germ cells contains a local estrogen source and also its own receptors for a possible autocrine estrogen regulation of spermatid differentiation in the testis.

The expression of estrogen receptors in human sperm cells is still a matter of debate. ER $\beta$ is the estrogen receptor isoform detected in testicular germ cells by many authors, while the presence of ER $\alpha$ in the same cells is widely controversial [7-9]. However, the expression of both ERs has been recently reported in mature spermatozoa [31-33].

It is generally accepted that residual cytoplasm of immature sperm contains discarded components of the original spermatids; therefore our results suggest that not only ER $\beta$ but also ER $\alpha$ could mediate estrogen action in spermatogenetic cells. According to this, a recent report demonstrated the presence of both estrogen receptor isoforms in round immature sperm cells of human ejaculate [32]. However, sperm cells with excess residual cytoplasm interact with epididymal fluid and fluids produced by accessory sex glands during their transit in reproductive ducts, as witnessed by their acquired motility, a property linked to the post-testicular sperm maturation. Therefore, it 
might be taken in account that these interactions could also influence the expression of sperm signalling proteins.

Spermatozoa with excess residual cytoplasm, in addition to the full-length ER $\beta$ isoform, showed also the expression of a $50 \mathrm{kDa} E R \beta$ form, which was lacking in mature sperm. A $50 \mathrm{kDa} E R \beta$, indicated as ER $\beta$ short form, has been recently described in round germ cells of human ejaculate [32] and a ER $\beta$ short form has been detected in human testis $[9,10]$. Therefore, it is reasonable to hypothesize that the ER $\beta$ variant of immature spermatozoa could correspond to the ER $\beta$ short form.

This interesting finding supports the hypothesis that estrogen could modulate their action through different ER forms during the sperm maturation process. Furthermore, ER $\beta$ immunolocalization in the tails gives the cue to further studies to verify if estrogen can regulate sperm motility in these ejaculated immature forms, as in normal sperm [31].

Regarding mature spermatozoa, the present investigation has confirmed our previous data [31] identifying only the full-length isoforms of the two ERs, particularly ERa in mid-piece region and ER $\beta$ in all the sperm tail. There are some discrepancies with a recent report showing ER $\alpha$ in the head of the mature sperm [33] but this could happen mainly from the use of different anti- ER $\alpha$ primary antibodies.

\section{Conclusion}

The present investigation demonstrated ER $\alpha$ and ER $\beta$ presence in excess residual cytoplasm of human immature sperm cells, suggesting the hypothesis that both the 'classical' ERs could able to mediate estrogen action in spermatogenetic cells. Furthermore, the presence of the short ER $\beta$ form in immature germ cells and its disappearance in mature sperm, support estrogen modulation via different ER forms during sperm maturation.

\section{Authors' contributions}

RV: the author responsible for performing the immunohistochemical expriments and participating in the analysis and interpretation of data.

SL: the author responsible for sperm isolation and protein extraction

AS: the author responsible for performing Western blot analysis

CA: the author responsible for conception, design, analysis and interpretation of data as well as of drafting manuscript

\section{Acknowledgements}

The authors thank prof. Antonietta Martire for the English reviewing of this manuscript. This work was supported by "Ministero dell'Università e della Ricerca Scientifica e Tecnologica" (Murst 60\%).

\section{References}

I. Hess RA: Estrogen in the adult male reproductive tract: a review. Reprod Biol Endocrinol 2003, 9: I-52.

2. Akingbemi BT: Estrogen regulation of testicular function. Reprod Biol Endocrinol 2005, 3:51.

3. Lambard S, Carreau S: Aromatase and oestrogens in human male germ cells. Int J Androl 2005, 28:254-259.

4. O'Donnell L, Robertson KM, Jones ME, Simpson ER: Estrogen and spermatogenesis. Endocr Rev 200I, 22(3):289-318.

5. Eddy EM, Washburn TF, Bunch DO, Goulding EH, Gladen BC, Lubahn DB, Korach KS: Targeted disruption of the estrogen receptor gene in male mice causes alteration of spermatogenesis and infertility. Endocrinology 1996, 137:4796-4805.

6. Smith EP, Boyd J, Frank GR, Takahashi H, Cohen RM, Specker B, William TC, Lubahn DB, Korach KS: Estrogen resistance caused by mutation in the estrogen-receptor gene in a man. $N$ Engl J Med 1994, 331:1056-1061.

7. Pentikainen V, Erkkila K, Suomalainen L, Parvinen M, Dunkel L: Estradiol acts as a germ cell survival factor in the human testis in vitro. J Clin Endocrinol Metab 2000, 85:2057-2067.

8. Makinen S, Makela S, Weihua Z, Warner M, Rosenlund B, Salmi S, Hovatta O, Gustafsson JK: Localization of oestrogen receptors alpha and beta in human testis. Mol Hum Reprod 200I, 7:497-503.

9. Saunders PT, Sharpe RM, Williams K, Macpherson S, Urquart H, Irvine DS, Millar MR: Differential expression of oestrogen receptor $\alpha$ and $\beta$ proteins in the testes and male reproductive system of human and non-human primates. Mol Hum Reprod 200I, 7:227-236.

10. Saunders PT, Millar MR, Macpherson S, Irvine DS, Groome NP, Evans LR, Sharpe RM, Scobie GA: ER $\beta$ I and ER $\beta 2$ splice variant (ER $\beta$ $c x / \beta 2)$ are expressed in distinct cell populations in the adult human testis. J Clin Endocrinol Metab 2002, 87:2706-27I5.

II. Aschim EL, Saether T, Wiger R, Grotmol T, Haugen TB: Differential distribution of splice variants of estrogen receptor beta in human testicular cells suggests specific functions in spermatogenesis. J Steroid Biochem Mol Biol 2004, 92:97-106.

12. Pelletier G, El-Alfy M: Immunocytochemical localization of estrogen receptors alpha and beta in the human reproductive organs. J Clin Endocrinol Metab 2000, 85:4835-4840.

13. Cooper TG, Ching-Hei Y, Fetic S, Sobhani A, Nieschlag E: Cytoplasmic droplets are normal structures of human sperm but are not well preserved by routine procedures for assessing sperm morphology. Hum Reprod 2004, 19:2283-2288.

14. Cooper TG: Cytoplasmic droplets: the good, the bad or just confusing? Human Reprod 2005, 20:9-11.

15. Rago V, Bilinska B, Palma A, Andò S, Carpino A: Evidence of aromatase localization in cytoplasmic droplet of human immature ejaculated spermatozoa. Folia Histochem et Cytobiol 2003, 41:23-27.

16. World Health Organization: Laboratory Manual for the Examination of Human Semen and Sperm-Cervical Mucus Interaction 3rd edition. New York, Cambridge University Press; 1999.

17. Bradford MM: A rapid and sensitive method for the quantization of microgram quantities of protein utilizing the principle of protein-dye binding. Anal Biochem 1976, 72:248-254.

18. Rago V, Maggiolini M, Vivacqua A, Palma A, Carpino A: Differential expression of estrogen receptors (ERalpha/ERbeta) in testis of mature and immature pigs. Anat Rec A Discov Mol Cell Evol Biol 2004, 28 I: I 234-1239.

19. Hermo L, Dworkin J, Oko R: Role of epithelial clear cells of the rat epididymis in the disposal of the contents of cytoplasmic droplets detached from spermatozoa. Am J Anat 1988, 183:107-124.

20. Kaplan M, Russell LD, Peterson RN, Martan J: Boar sperm cytoplasmic droplets: their ultrastructure, their numbers in the epididymis and at ejaculation and their removal during isolation of sperm plasma membranes. Tissue Cell 1984, 16:455-468. 
21. Cortadellas N, Durfort M: Fate and composition of cytoplasmic droplet of hamster epididymal spermatozoa. J Morphol I994, 221:199-210.

22. Huszar G, Patrizio P, Vigue L, Willets M, Wilker C, Adhoot D, Johnson L: Cytoplasmic extrusion and the switch from creatine kinase $b$ to isoform are completed by the commencement of epididymal transport in human and stallion spermatozoa. J Androl 1998, 19:1 I-20.

23. Mak V, Jarvi K, Buckspan M, Freeman M, Hechter S, Zini A: Smoking is associated with the retention of cytoplasm by human spermatozoa. Urology 2000, 56:463-466.

24. Zini A, Defreitas G, Freeman M, Hechter S, Jarvi K: Varicocele is associated with abnormal retention of cytoplasmic droplets by human spermatozoa. Fertil Steril 2000, 74:46I-464.

25. Keating J, Grundy CE, Fivey PS, Elliott M, Robinson J: Investigation of the association between the presence of cytoplasmic residues on the human sperm midpiece and defective sperm function. J Reprod Fertil 1997, I 1 0:71-77.

26. Fisher MA, Willis J, Zini A: Human sperm DNA integrity: correlation with sperm cytoplasmic droplets. Urology 2003, 61:207-211.

27. Rao B, Soufir JC, Martin M, David G: Lipid peroxidation in human spermatozoa as related to midpiece abnormalities and motility. Gamete Res 1989, 24:127-134.

28. Gomez E, Buckingham DW, Brindle J, Lanzafame F, Irvine DS, Aitken RJ: Development of an image analysis system to monitor the retention of residual cytoplasm by human spermatozoa: correlation with biochemical markers of the cytoplasmic space, oxidative stress, and sperm function. J Androl 1996, I 7:276-287.

29. Agarwal A, Saleh RA, Bedaiwy MA: Role of reactive oxygen species in the pathophysiology of human reproduction. Fertil Steril 2003, 79:829-843.

30. Baker MA, Aitken RJ: Reactive oxygen species in spermatozoa: methods for monitoring and significance for the origins of genetic disease and infertility. Reprod Biol Endocrinol 2005, 3:67.

31. Aquila S, Sisci D, Gentile M, Middea E, Catalano S, Carpino A, Rago V, Ando' S: Estrogen receptor (ER)alpha and ER beta are both expressed in human ejaculated spermatozoa: evidence of their direct interaction with phosphatidylinositol-3-OH kinase/Akt pathway. J Clin Endocrinol Metab 2004, 89: | 443- |45I.

32. Lambard S, Galeraud-Denis I, Saunders PT, Carreau S: Human immature germ cells and ejaculated spermatozoa contain aromatase and oestrogen receptors. I Mol Endocrinol 2004, 32:279-289.

33. Solakidi S, Psarra A-MG, Nikolaropoulos S, Sekeris CE: Estrogen receptors $\alpha$ and $\beta$ (ER $\alpha$ and $E R \beta)$ and androgen receptor (AR) in human sperm: localization of ER $\beta$ and $A R$ in mitochondria of the midpiece. Hum Reprod 2005, 20:348I-3487.

Publish with Bio Med Central and every scientist can read your work free of charge

"BioMed Central will be the most significant development for disseminating the results of biomedical research in our lifetime. "

Sir Paul Nurse, Cancer Research UK

Your research papers will be:

- available free of charge to the entire biomedical community

- peer reviewed and published immediately upon acceptance

- cited in PubMed and archived on PubMed Central

- yours - you keep the copyright

Submit your manuscript here:

http://www.biomedcentral.com/info/publishing_adv.asp
BioMedcentral 